ljaz Uddin

\title{
Impact of inflation on economic growth in Pakistan
}

\section{KEYWORDS}

inflation;

economic growth;

Pakistan

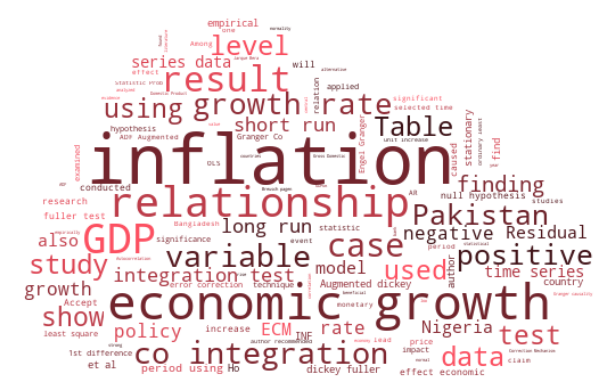

Word Cloud Generated by:

https://wordscloud.pythonanywhere.com/

FOR CITATION

\section{ABSTRACT}

Introduction. High and sustained economic growth with low inflation is the central objective of the macroeconomic policy makers. Therefore, inflation has been one of the most researched topics in macroeconomics for the last many years because it has serious implications for GDP growth. The main aim of this empirical study to examined the relationship b/w (GDP) Gross Domestic Product Growth and inflation in Pakistan by using time series data from 1990 to 2015.

Methodology. This study apply (ADF) Augmented dickey fuller test for stationary, and then, Engel Granger Co-integration test, for short run and long run association.

Results. There is a strong positive and significance relationship between GDP growth and inflation in Pakistan. Which indicate that is a 1 unit increase an inflation rate will caused by GDP increased by 0.27 unit.

Uddin, I. (2021). Impact of inflation on economic growth in Pakistan. Economic consultant, 34 (2), 33-41. doi: 10.46224/ ecoc.2021.2.4 


\section{INTRODUCTION}

$\mathrm{T}$

o attain sustainable economic growth coupled with price stability continues to be the central objective of macroeconomic policies for most countries in the world today. Among others the emphasis given to price stability in conduct of monetary policy is with a view to promoting sustainable economic growth as well as strengthening the purchasing power of the domestic currency [1].

Economic growth and the rate of inflation is central subject of macroeconomics policy. Among many variables that can be stated as the determinant of economic growth is inflation. However there is no a clear cut or straight forward decision about the relationship between economic growth and inflation. Researchers investigate about inflation and economic growth and have arrived come up with different views. It has been a controversial in both theory and empirical findings [2].

If inflation is indeed detrimental to economic activity and growth, then how low should inflation be? The answer to this question, obviously depends on the nature and structure of the economy, and will vary from country to country. Numerous studies with several theories have been carried out, which specifically aimed at examining the relationship between inflation and growth [3]

A series of studies found no conclusive empirical evidence for either a positive or a negative association between inflation and economic growth, notable among these studies are Wai, 1959; Bhatia, 1960; Dorrance, 1963, 1966, Johansen (1967). The second strand of the literature found a negative correlation between inflation and economic growth. Among these studies are Fisher (1993) De Gregorio (1993) Barro (1995, 1996); Brunno and Easterly (1995); Malla (1997); Faria and Carneiro (2001) Dewan \& Hussein (2001). While the third strand of the literature found a positive relationship between inflation and economic growth.

In this paper, we will examine inflation and its effect on economic growth in Pakistan.

\section{LITERATURE REVIEW}

Majumder [4] conducted a research the impact of inflation on economic growth in the event of Bangladesh, they were selected the time period (1975 to 2013). The used (ADF) Augmented dickey fuller test for stationary. This research thesis its independent variable (inflation, remittances, money supply) and while the GDP is dependent variable. The Author fined the results there is positive relationship b/w economic growth of GDP and inflation in Bangladesh.

Hossin [5] examined that inflation and economic growth relationship in Bangladesh. They used time series data from (1961 to 2013). They used the Granger causality test and also used 
error correction model and co integration test. They finding is economic growth is positively affect inflation. If rises the inflation rate, then inflation effect economic growth negatively.

Umaru and Zabairu [6] analyzed the impact of inflation on economic growth and development in case of Nigeria. They were using time series data from (1970 to 2010). They are used Granger causality test and augmented dickey fuller test. They are finding results inflation not caused GDP but GDP caused inflation. The inflation is positive effect on economic growth and also encourage the productivity. The Author recommended the policy the Nigerian economy not increase their productivity it results the price level also low. This lead to Boom phase in economy.

Enu et el. [7] conducted a research that inflation rate and growth rate relationship, in the country of china. By using time series data from (1980 to 2012). They are using the (ordinary least square) OLS technique. They finding the results there is strong linear negative relationship $\mathrm{b} / \mathrm{w}$ inflation and GDP, growth rate. If $1 \%$ decrease inflation rate caused by growth rate increased by $0.086 \%$. In other case if $1 \%$ increase inflation rate caused growth rate decrease by $0.086 \%$. These value are statistical significant at $5 \%$ level. The author recommended the policy to reduce the inflation to increase the growth rate.

Saaed and Afaf [8] examined the economic growth and inflation in case of Kuwait by using annul data for the period of (1985 to 2005). They are used error correction model and co integration test. They find there is long run negative significant relationship b/w GDP and CPI. The author say that conclusion is lead to Kuwait bank of monetary policy.

Ayyoub et al. [9] examined Do inflation impact the economic growth in the event of Pakistan. They used time series data for the period of (1973 to 2010). They are using the OLS technique. They conclude that there is significant negative relationship b/w economic growth and inflation in Pakistan. The author policy recommended the Stat bank of Pakistan is responsible to keep inflation less than $7 \%$ its results our economic growth is rises.

Shuaib et al. [10] investigated the inflation and its impact on economic growth in case study of Nigeria. They are used the time series data from (1960 to 2012). They are used the co integration test. They finding no co integration relationship b/w economic growth and inflation in given data. The author gives recommended policy the government lead to inflation rate one single digit number it is very necessary for a country.

Salian and gopakumar [11] the economic growth and inflation an empirical evidence of India for the period of (1973 to 2008). They are using augmented dickey fuller test and Philips-Perron test for unit roots, and co integration test. They find there is long run negative relationship b/w GDP growth rate and inflation.

Obi et al. [12] examined the inflation and economic growth in case of Nigeria for the period of (1981 to 2014) by using (2sls) two stags least square. The study conclude that inflation is beneficial for growth and while the significance of growth due to inflation. The final finding the negative relation $\mathrm{b} / \mathrm{w}$ growth and inflation on the other hand positive relation b/w inflation and growth. 
Vinayagathasan [13] conducted a research growth and inflation in case of 32 economies of Asia. They are selected time period from (1980 to 2009) by using regression analysis, they have created the endogenity problem in the model. There finding inflation have $1 \%$ level of significance, if inflation have around $5.43 \%$. The growth rate is affected due to inflation in strong. The author recommended that our results are beneficial for central bank.

Idalu [14] empirically investigated the inflation and its effect of economic growth in the event of Nigeria for the period of (1970 to 2013) by using vector autoregressive model. They find the result there is intersection $\mathrm{b} / \mathrm{w}$ the variable quantity long run for five years. The results show that in one impermanent a price level for consumer shocks, which claims that low positive short run effect of GDP in Nigerian country.

Osuala et al [15] conducted the empirical study the effect of inflation on growth about in Nigeria. They are using the time series data from (1970 to 2011) by using (ADF) Augmented dickey fuller test and Philips perron test. The author finding economic growth and inflation have significance positive relation in case of Nigeria.

Barrio [16] has empirically study about economic growth and inflation in case of hundred countries for the period of (1960 to 1990) by using multiple regression technique. The result show that if increase average inflation 10 percent in per year, its results the reduction of GDP by 0.3 percentage.

Chaudhary et al. [17] analyzed empirically do inflation matter for sectorial growth in case study of Pakistan by using time series data from (1972 to 2010) by using OLS and 2SLS and autoregressive method. They finding results inflation is beneficial for manufacture growth there is positive relationship. And also show that inflation and agriculture sector have significance positively related.

Bandula et al. [18] conducted the empirical study the relationship b/w economic growth and inflation in the evidence of three Asian countries for the period of (1980 to 2010) by using (ADF) Augmented dickey fuller, granger causality test and co integration technique are applied. The author claim in case of Sarilanka there is long run negative relationship b/w inflation and economic growth. And also in case of India and china have no statistical relationship, the author claim this paper is important for policy makers.

Olu and Idih [19] examined the economic growth and inflation in the country of Nigeria. They selected the time period from (1980 to 2013). They are applied are OLS ordinary least square technique. There finding inflation rate have positive in significance effect on economic growth. They also claim if GDP increase the inflation also increase in this stage no positive effect of monetary policy to control inflation. The author recommended if monetary authority stabilized the inflation rate the economic growth itself betterment in Nigeria.

Ghosh et al. [20] analyzes the empirical study that economic growth and inflation in case study of Bangladesh. They selected time series data from (1978 to 2010) by using co integration test and ADF test are applied.

Wajid and Kalim [21] analyzed the effect of economic growth rate and inflation on unemployment in the event of Pakistan, for the period of (1973 to 2010) by using ADF and co 
integration test. They find the results there is long run and short run negative relationship of economic growth effect on unemployment.

\section{RESEARCH METHODOLOGY}

\section{Universe of the study}

This study has been conducted in case of Pakistan to check the impact of inflation on economic growth in Pakistan.

\section{Research Hypothesis:}

$\mathrm{Ho} \neq$ there is no relationship between inflation and economic growth.

\section{Source of data}

The data on inflation and GDP growth has been taken from WDI.

\section{Model Specification}

GDPGRt $=\alpha_{1}+\beta_{1} I N F_{t}+\varepsilon_{t}$

Where, INF: inflation; GDPGR: Gross Domestic Product growth rate

\section{Definition of Variables}

INF: the general and persistence rise in the general price level.

GDPGR: It denotes the Gross Domestic Product growth rate of a country.

\section{RESULTS AND DISCUSSION}

Table 1

Results of ADF

\begin{tabular}{|l|c|c|c|c|c|}
\hline \multicolumn{1}{|c|}{ Variables } & At Level & Prob. & 1st Difference & Prob. & Stationary at \\
\hline GDPGR & -0.369301 & 0.1643 & -1.137754 & $\mathbf{0 . 0 0 0 0}$ & I (1) \\
\hline INF & -0.357863 & 0.2611 & -1.262221 & $\mathbf{0 . 0 0 0 0}$ & I( 1$)$ \\
\hline
\end{tabular}

The above table show that both variables GDP and inflation are non-stationarity AT Level, but we are converted to 1 st difference. In this case we have both variables such as GDP and inflation are stationary at 1 st difference verifying the same level of integration, which allows us to used Johansen's co-integration test and also used for short run employ Engel Granger Co integration.

\section{Engel Granger Co integration test:}

This study is based on Engel Granger co integration test, because all variables are stationary at $1 \mathrm{st}$ difference. Engel granger co integration are capable to confirm long run and short run relationship. We will proceed for short run relationship and if not, then there is no need to go for short runs relationship, which is based on (ECM) Error Correction Mechanism. 
Results of Ordinary least squares

\begin{tabular}{|l|c|c|c|}
\hline \multicolumn{1}{|c|}{ Variables } & Coefficient & t-Statistic & Prob. \\
\hline INF & 0.252548 & 1.769656 & 0.0013 \\
\hline $\mathrm{INF}_{-1}$ & 0.608568 & 2.197378 & 0.0394 \\
\hline $\mathrm{INF}_{-2}$ & 0.073202 & -0.286896 & 0.7770 \\
\hline $\mathrm{R}^{2}$ & 0.47 & & \\
\hline
\end{tabular}

The above table 2 shows that the results of ordinary least square. There occur positive relationship b/w inflation and GDP. Displaying a one unit increase in inflation leads to 0.25 unit increase in GDP.

Table 3

Long run relation $\mathrm{B} / \mathrm{w}$ inflation and GDP

\begin{tabular}{|l|l|l|l|}
\hline \multicolumn{2}{|l|}{} & \multicolumn{1}{c|}{ t-Statistic } & \multicolumn{1}{c|}{ Prob. $^{*}$} \\
\hline \multicolumn{2}{|l|}{ Augmented Dickey-Fuller test statistic } & -5.018240 & 0.0005 \\
\hline Test critical values: & $1 \%$ level & -3.724070 & \\
\hline & $5 \%$ level & -2.986225 & \\
\hline & $10 \%$ level & -2.632604 & \\
\hline
\end{tabular}

Null Hypothesis: there is no long run relation b/w inflation and GDP

Table 4

(ECM): Error correction Mechanism for short run relationship

\begin{tabular}{|l|c|c|c|}
\hline \multicolumn{1}{|c|}{ Variable } & Coefficient & t-Statistic & Prob. \\
\hline Constant & 101.7254 & 63.03645 & 0.0000 \\
\hline INF & 0.274497 & 2.366465 & 0.0287 \\
\hline ECM(-1) & 0.605639 & 2.272891 & 0.0079 \\
\hline AR(1) & 0.749974 & 2.315175 & 0.0319 \\
\hline AR(2) & 0.125497 & 0.400791 & 0.6930 \\
\hline R2 & 0.599283 & & \\
\hline F-statistic & 5.683004 & & \\
\hline F-statistic (prob) & 0.00078 & & \\
\hline
\end{tabular}

In direction to find the short run relationship we applied error correction mechanism (ECM) the result obtained from ECM shows that there exist short run positive relationship b/w gross domestic product (GDP) and inflation in case of Pakistan. A one unit increase in inflation $0.27 \%$ unit increase in GDP having statistical significant relationship. Further, ECM (-1) shows that the speed of adjustment toward long run equilibrium, means that almost $60 \%$ of adjustment takes place every year toward equilibrium.

Further, $59 \%$ of variation in GDP caused by inflation in case of Pakistan and $41 \%$ variation caused GDP by other factors. 


\section{Residual diagnostic test:}

Residual Diagnostics ECM

\begin{tabular}{|l|c|c|c|}
\hline \multicolumn{1}{|c|}{ Cheeked } & Tests & F-Statistics & Probability \\
\hline Normality & (Jarque-Bera) & 0.486989 & 0.783884 \\
\hline Heteroskedasticity & Breusch - pagen & 0.197093 & 0.8225 \\
\hline Auto Correlation & AR(1) AR(2) & ----- & ------- \\
\hline
\end{tabular}

In the above 4.10 table the residual diagnastice test are applied for to checked out the error term, normality, hetrocedasticity and Auto correlation. To find out the Residual or error term results the following criteria.

Table 6

Hypothesis of Residual of ECM

\begin{tabular}{|l|l|l|}
\hline Jarque-Bera & Ho: Data is normal distribute. & Accept Ho. \\
\hline Breusch - pagen & Ho: data is Homosidasticity & Accept Ho. \\
\hline Autocorrelation & Ho: data is No Autocorrelation & Accept Ho. \\
\hline
\end{tabular}

The table no 6, show that residual have normally distribution, which is desirable for Assumption of Residual. The null hypothesis of the normality, Jarque-Bera statistic is data is normal distributed and alternative hypothesis data is not Normal distributed, so we will accept the Null hypothesis. The second rows of the above table show that residual is constant variance meaning that data is Homoscedasticity. The null hypothesis of the Breusch - pagen test is data is homoscedasticity. So we will reject alternative hypothesis and accept the null hypothesis. The 3rd row show that data is No Autocorrelation, so if we see the table no 4.9 the Durban Watson statistics value which is 1.88 , which is near to 2 , so we will accept Null hypothesis and Reject Alternative hypothesis. The above result show that our model is successful and acceptable, because our model is clear the disturbance of model.

\section{CONCLUSION}

This empirical study determines the relationship between GDP growth rate and inflation rate in Pakistan for the period of 1990 to 2015. Our dependent variable is GDP and while inflation is independent variable. We are using (ADF) Augmented dickey fuller test for stationary, our variable, inflation and GDP AT Level non stationary, after 1st difference our variable is stationary. After using Johansson co integration test, and Engel Granger co integration methods to find the long run as well as short run association b/w inflation and GDP growth rate in case of Pakistan. Hence proved that there is a strong positive linear relationship between GDP growth rate and inflation rate in Pakistan. 


\section{REFERENCES}

1. Kasidi, F., \& Mwakanemela, K. (2013). Impact of inflation on economic growth: A case study of Tanzania. Asian Journal of empirical research, 3 (4), 363-380.

2. Majumder, S. C. (2016). Inflation and its impacts on economic growth of Bangladesh. American Journal of Marketing Research, 2 (1), 17-26.

3. Hossin, M. S. (2015). The relationship between inflation and economic growth of Bangladesh: An empirical analysis from 1961 to 2013. International Journal of Economics, Finance and Management Sciences, 3 (5), 426-434.

4. Majumder, S. C. (2016). Inflation and Its Impacts on Economic Growth of Bangladesh. American Journal of Marketing Research, 2 (1), 17-26.

5. Hussain, M. E., \& Haque, M. (2017). Empirical Analysis of the Relationship between Money Supply and Per Capita GDP Growth Rate in Bangladesh. Journal of Advances in Economics and Finance, 2 (1), 55.

6. Umaru, A., \& Zubairu, A. A. (2012). Effect of inflation on the growth and development of the Nigerian economy (An empirical analysis). International Journal of Business and Social Science, 3 (10).

7. Enu, P., Attah-Obeng, P., \& Hagan, E. (2013). The relationship between GDP growth rate and inflationary rate in Ghana: an elementary statistical approach. Academic Research International,4 (5), 310.

8. Saaed, A. A. (2008). Inflation and Economic Growth in Kuwait: 1985-2005-Evidence from Co-Integration and Error Correction Model. Applied Econometrics and International Development, Euro-American Association of Economic Development, vol. 7(1).

9. Ahmed, S., \& Mortaza, M. G. (2010). Inflation and economic growth in Bangladesh: 1981-2005 (No. id: 3033).

10. Ayyoub, M., Chaudhry, I. S., \& Farooq, F. (2011). Does inflation affect economic growth? The case of Pakistan. Pakistan journal of social sciences, 31 (1), 51-64.

11. Shuaib, I. \& Augustine, Ochube \& Frank, A. (2015). Impact of Inflation Rate on the Economic Growth in Nigeria. British Journal of Economics, Management \& Trade, 9, 1-11. DOI: 10.9734/BJEMT/2015/15293.

12.Salian, P., \& Gopakumar, K. (2008). Inflation and Economic Growth in India-An Empirical Analysis. Indian Economic Service, New Delhi and Gopakumar. K, Faculty, BIET-MBA Programme, Davangere, Karnataka.

13. Obi, K. O., Yuni, D. N., \& Ihugba, O. A. Inflation and growth nexus in Nigeria: an investigation into the simultaneous relationship. International Journal of Development and Economic Sustainability, 4 (3), 25-32.

14. Vinayagathasan, T. (2013). Inflation and economic growth: A dynamic panel threshold analysis for Asian economies. Journal of Asian Economics, 26, 31-41.

15. Idalu, R. E. (2015). Impact of Inflation on Economic Growth: Case Study of Nigeria 
(1970-2013) (Doctoral dissertation, Eastern Mediterranean University (EMU)-Dogu Akdeniz bniversitesi (DAU)).

16. Osuala, A. E., Osuala, K. I., \& Onyeike, S. C. (2013). Impact of inflation on economic growth in Nigeria-A causality test. Transcampus Journal, (11), 1.

17. Barro, R.J. (1995). Inflation and Economic Growth (No. w5326). National Bureau of Economic Research. https://doi.org/10.3386/w5326

18. Chaudhry, I. S., Ayyoub, M., \& Imran, F. (2013). Does Inflation matter for Sectoral growth in Pakistan? An Empirical Analysis. Pakistan Economic and Social Review, 71-92.

19. Jayathileke, P. M. B., \& Rathnayake, R. M. K. T. (2013). Testing the link between inflation and economic growth: Evidence from Asia. Modern Economy, 4 (2), 87-92. doi: 10.4236/ me.2013.42011.

20. Olu, J. F., \& Idih, E. O. (2015). Inflation and economic growth in Nigeria. Journal of Economics and International Business Management, 3 (1), 20-30.

21. Hossain, M. E., Ghosh, B. C., \& Islam, M. K. (2012). Inflation and Economic Growth in Bangladesh. Researchers World, 3 (4), 85.

22. Wajid, A., \& Kalim, R. (2013). The impact of inflation and economic growth on unemployment. In Proceedings of 3rd International Conference on Business Management. Available at: http://escholar.umt.edu.pk:8080/jspui/bitstream/123456789/928/1/IC3Dec-2012-083.pdf (accessed 15 May 2021)

\section{INFORMATION ABOUT THE AUTHOR}

ljaz Uddin (Pakistan, Matta Swat) - Student, PhD Economics. School of Economics. Abdul Wali Khan University Mardan. E-mail: ijazuddin01@gmail.com. ORCID ID: 0000-00027231-109X

\section{(1) (1) \\ open Access}

Available: https://statecounsellor.wordpress.com/2021/05/30/uddin-3/

Received: Feb 6, 2021 | Accepted: May 3, 2021 | Published: Jun 1, 2021

Editor: Mohamed R. Abonazel, PhD in Statistics and Econometrics. Cairo University, EGYPT

Copyright: ( $) 2021$ Uddin, I. This is an open access article distributed under the terms of the Creative Commons

Attribution License, which permits unrestricted use, distribution, and reproduction in any medium, provided the original author and source are credited.

Competing interests: The authors have declared that no competing interests exist. 